\title{
THE GREEK CHURCH FATHERS AND RAHAB
}

\author{
H.F. Stander \\ (University of Pretoria)
}

\begin{abstract}
Rahab, the harlot, was highly regarded in the Early Church, despite her former questionable profession. The Church Fathers often used her as an example to illustrate various theological truths. This study will focus on the role and function of Rahab in the writings of the Greek Church Fathers.
\end{abstract}

\section{Introduction}

According to rabbinic tradition Rahab was one of the four most beautiful women in the world and an ancestress of eight prophets, including Jeremiah and a prophetess (Ross 1962:6). Rabbinic exegesis also shows a great interest in Rahab (Beek 1982:41). Yet the story of Rahab cannot be said to occupy a particularly prominent place in the Bible (Newman 1985:167). Greenspoon (1992:612) agrees and says that "the role Rahab plays in Jewish and Christian exegetical traditions ... is larger than that attributed to her in the OT itself."

Since Greenspoon's remark concerning Rahab in early Christian exegetical traditions is correct, it is a pity that no proper study on the role and function of Rahab in the early Christian tradition has been done. Hanson (1978) did a study with the title "Rahab the harlot in early Christian tradition", but he discussed only the three occurrences of Rahab in the New Testament, as well as 1 Clement's treatment of this narrative. Thus a more comprehensive study of how the Church Fathers dealt with this woman, is still lacking. The aim of this investigation is then to try to fill this gap. In this article we will discuss the Greek Church Fathers' exegetical and hermeneutical handling of this narrative (and especially the role of the harlot Rahab). In a separate study in this same volume another scholar will discuss how the Latin authors viewed Rahab.

\section{Are Rachab and Rahab the same woman?}

The LXX and the New Testament use the name ${ }^{\mathrm{P}} \alpha \alpha \dot{\alpha} \beta$ when they refer to the harlot of Jericho. In the genealogy of Matthew (Mt. 1:5) we read that the name of the wife of Salmon and the mother of Boaz is 'P $\alpha \chi \alpha$ ' $\beta$. Many articles have been written on the identity of this woman in the Gospel of 
Matthew. Some scholars argue that 'P $\alpha \alpha$ ' $\beta$ (henceforth Rahab) and 'P $\alpha \chi \alpha$ ' $\beta$ (henceforth Rachab) are not the same woman. Quin (1981) states the possibility that Matthew used a Hebrew source about the Davidic family tree which used the Hebrew equivalents of $\Sigma \alpha \lambda \mu \omega \dot{\nu}$ and 'P $\alpha \chi \alpha \dot{\alpha} \beta$ for the parents of ßóєৎ, without in any sense implying that this was the harlot of Jericho in the Joshua saga (see Quin 1981:225-228 for a survey of the main reasons for this argument). Other scholars (see, for example, Brown 1982:79-80), on the other hand, argue that the woman in Matthew's genealogy is indeed the harlot of Jericho. Brown also offers various arguments for his point of view. He says, for example, that every other name in the first two sections of Matthew's genealogy is the name of an identifiable figure in the Greek Bible (even if it is peculiarly spelled). He also argues that in that genealogy Rachab's name occurs in approximately the place where the Biblical Rahab would have to appear were she included. Furthermore, Brown points out that various names in the Matthean list are spelled differently when one compares them with the names in the Septuagint.

Origen (Comm. on Mt. 1.5) has no doubt that Rachab in the Matthean genealogy is definitely not the same as Rahab of the Old Testament. He says "Then [Matthew] notes 'P $\alpha \chi \alpha \dot{\beta} \beta$, who bore Bóєৎ, the grandfather of Jesse, by Salmon. She is an insignificant woman, mentioned nowhere else in Scripture, who has dropped ex machina - so to speak - into the sphere of the gospel". 1 Elsewhere (In Lk 28) he again says "we do not know Rahab".

But not all the Church Fathers agreed with Origen. Chrysostom (Hom. on Mt. 1.14; see also Theodoretus, Questions on the Octateuch, on Ruth 1) finds it remarkable that Matthew is prepared to mention women in his genealogy, and even more remarkable that Matthew did not mention eminent women such as Sarah and Rebekah. However, Matthew preferred to mention the wife of Uriah, Tamar, Rahab and Ruth, who had received fame because of negative events. Chrysostom uses these puzzling issues in the book of Matthew to show how difficult it is to understand the Scriptures. He says that most people think that only prophetic writings are difficult to comprehend, but these examples show that often it is difficult to answer questions even on the Gospel of Matthew. Nevertheless, it is clear that Chrysostom regards Rahab as the person whom we had met in the Old Testament. 
In another homily (Hom. on Mt. 3.5) Chrysostom gives us an answer why he thinks these bad women were mentioned in Matthew's genealogy. He says that Matthew included these women in his list, because he wanted to show to us that "Jesus came to do away with all our ills". Matthew also wanted to show that Christ did not come as a judge, but that He came as a physician. The fact that Rahab is mentioned, shows that "just as those of old took harlots for wives, even so God too espoused unto Himself the nature which had played the harlot".

\section{Rahab was a harlot}

The Bible (Jos. 2:1; Heb. 11:31) tells us that Rahab was a harlot (or prostitute). Though all the Church Fathers praised her, they always referred

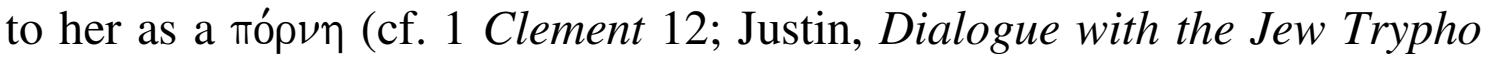
111; Amphilochius, On the sinful woman orat. 4; Athanasius, On the life of the holy Syncletica MPG 28.1520; Eusebius, Commentary on Psalms MPG 23.1048; Gregory of Nazianzus, On the love of the poor MPG 35.860; Chrysostom, On penitence MPG 49.330). Rahab never managed to shake off this epithet. It was not because the Church Fathers doubted her conversion or righteousness. It was rather a technique to emphasize the wonder of her repentance. Hanson (1978:54) says that the rabbinic tradition also magnified Rahab's profligacy in order to bring out the wonder of her repentance.

\section{Rahab as an example of faith}

The author of Hebrews (11:31) says that "by faith the prostitute Rahab, because she welcomed the spies, was not killed with those who were disobedient". Many Church Fathers emphasized the faith which Rahab displayed (1 Clement 12.1\&8; Chrysostom, Hom. on Hebrews 26.3; Hippolytus, Commentary on the Book Daniel 2.19). One may ask why Rahab is mentioned for her faith. What "faith" did she display? Chrysostom gives the answer (Hom. 3 on Romans). He says that Rahab could have said to herself: "And how can they that are captives and exiles, and refugees, and live the life of vagabond tribes, get the better of us who have a city, and walls, and towers?" As a matter of fact, these were indeed the type of questions which were asked by the forefathers of these spies. When they saw the tall men, they questioned the manner of victory, and eventually all of them perished, without battle or array. Chrysostom then uses these accounts to highlight the pit of unbelief versus the wall of faith. 
Chrysostom adds that because of the faith of Rahab, she became the

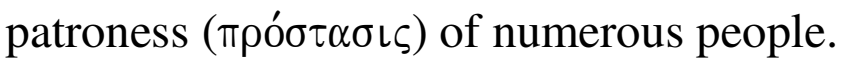

In another homily (Hom. on Hebr. 27.3), Chrysostom again mentions the faith of Rahab. He says that when she heard what the men had related, she immediately believed. She did not argue that she would be with her many friends. And if Rahab managed to believe, it is a disgrace for us to appear to be more faithless then even a harlot. ${ }^{3}$

Note also that Rahab had faith in God for her salvation, while the spies fixed their hope on Rahab for their salvation (Origen, Selections on Joshua MPG 12.820).

\section{Rahab as an example of hospitality}

Based on Hebrew 11:31, the Church Fathers often praised Rahab for the hospitality $(\phi \iota \lambda 0 \xi \in \nu i \alpha)$ which she had shown to Joshua's messengers/spies (see 1 Clement 12.1; Clement of Alexandria, Miscellanies 4.17). Gregory of Nazianzus (Concerning the love for the poor MPG 35.860) says that both good and bad people can show hospitality. Lot, the Sodomite, is an example of a righteous person who showed hospitality, while Rahab the harlot is an example of a sinner who showed hospitality. Because of her hospitality, Rahab received salvation.

\section{Rahab as a "prophetess"}

Clement, the bishop of Rome in the first century, said that Rahab was not only an example because of her faith, but "there was also prophecy in the

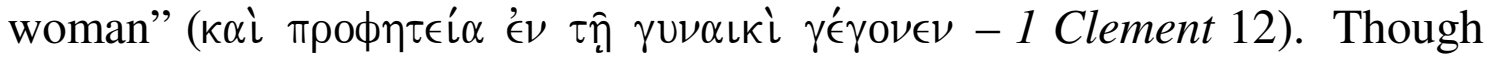
Rahab herself was not a prophetess, she served as a "prophetess" when she hung out a scarlet thread from her house. Clement interpreted this as foreshadowing that all who believe in God shall have redemption through the blood of Christ. Justin (Dialogue with the Jew Trypho 111) elaborates on this theme and says that Rahab's scarlet thread is a symbol to show that all those who were at one time harlots and unrighteous now have the promise of salvation. Irenaeus (Against Heresies 4.20) also mentions that Rahab was preserved through faith of the scarlet sign, and he, too, sees this as a foreshadowing of the blood of Christ (see also Theodoretus, Questions on the Octateuch, Joshua 2).

The messengers who were hid by Rahab were also a type of Christ: these 
messengers foretold what would happen to the city, and Christ, too, shared God's plan with us (Epiphanius, Against Heresies vol. 3, 62).

\section{Rahab as a model of repentance}

In his Catechetical Lectures (Lecture 2.9), Cyril of Jerusalem calls upon his readers to repent and to turn to God. He says that sins which they have committed, do not have to hinder them from repenting. He then calls upon Rahab who "openly and publicly" practiced her harlotry. Yet she was saved because of her repentance. For those who might ask where we read of Rahab's repentance, Cyril refers to Rahab's confession: "For your God is God in heaven and upon earth" (Jos. 2:11). Rahab did not rely on her own life, because she was too sinful. But these words show that Rahab placed her hope on the God of Israel.

And for those who might ask how one knows that Rahab was indeed saved, Cyril refers to the words of Psalm 86(87):4: "I will make mention of Rahab

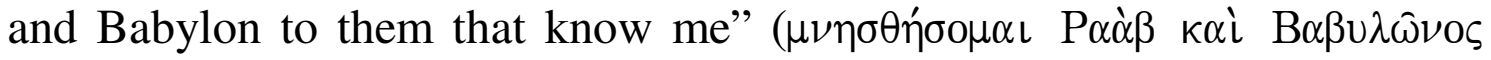

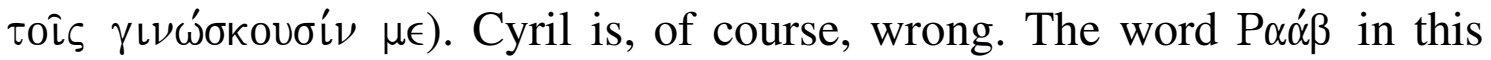
verse is merely a poetic name for Egypt (cf., for example, Bratcher 1991:759). ${ }^{4}$ Psalm 86(87):4 has therefore nothing to do with Rahab the harlot. But it helped Cyril to prove his point! But other Church Fathers also interpreted Psalm 86(87):4 as referring to Rahab the harlot (see, for example Eusebius, Commentary on Psalms MPG 23.1049; Gregory of Nyssa, On the Song of Songs 2).

Chrysostom (Hom. on Mt. 67.4) says that we cannot consume or spend grace, because it is like a fountain springing up constantly. That is why sinners are healed both soul and body by his fullness. Rahab is an example of someone who was saved, though she was a sinner.

Amphilochius (The sinful woman orat. 4), too, refers to Rahab the harlot as an example of someone who changed her way of life, and he then calls her new life virtuous (' $\left.\mathcal{\alpha}^{\prime} \rho \in \tau 0 \varsigma\right)$. Athanasius (The Life of the Holy Syncletica MPG 28.1520) mentions various people whose life was changed, namely Paul who was a persecutor, but who became a "chosen instrument (Ac. 9:15), the robber who became the first person to open the door of Paradise, and Rahab the harlot, who was saved because of faith.

Nineveh had three days to turn to the Lord, while Jericho had seven days to repent (Chrysostom, On Repentance MPG 49.329). But God did not send a 
prophet or an evangelist to this city, as in the case of Nineveh. Chrysostom

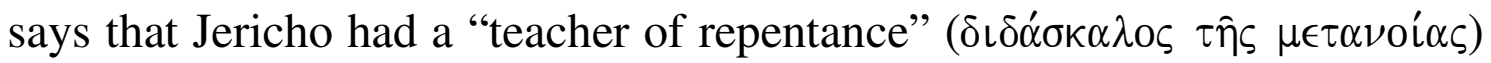

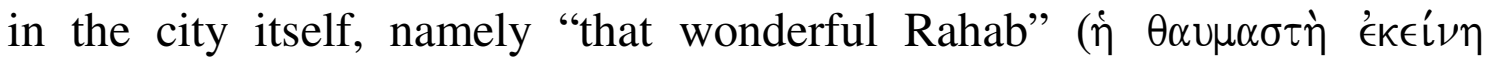

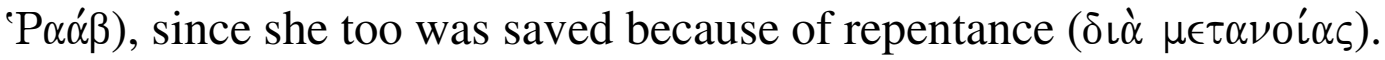

Rahab showed us the way of repentance. God will be even more willing to grant us salvation (Chrysostom, On repentance MPG 49.331; see also Theodoretus, Questions on the Octateuch, Joshua 2). We must merely believe and repent.

\section{Rahab was a type of the Church}

As other Church Fathers, Chrysostom (On repentance MPG49.331) too

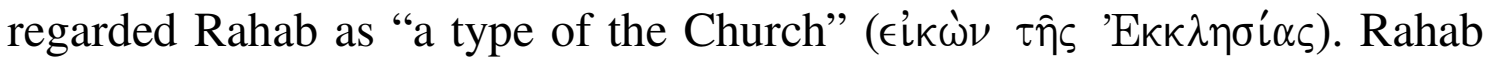
was previously involved with the harlotry of demons ( $\dot{\eta} \pi \rho \rho \nu \epsilon i \alpha \tau \hat{\omega} \nu$

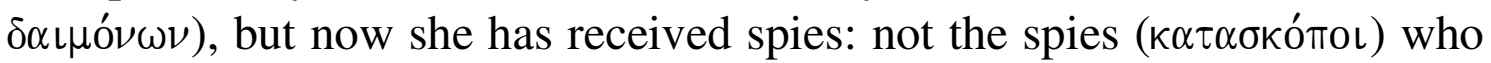

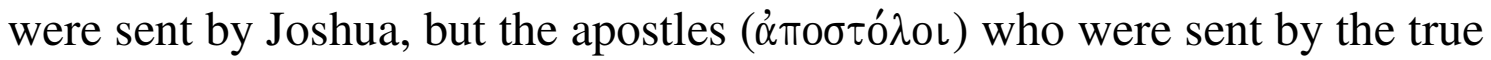
Saviour (the same argument is found in Theodoretus, Questions on the Octateuch, Joshua 2). The Jews were not willing to accept God's instruction to obey the one true God only, but the Church obeyed it. Chrysostom says that is why Rahab is worthy of all praise, and worthy to be called a "type of the Church". That is also the reason why Paul ${ }^{5}$ did not disapprove of Rahab because of her previous profession. However, because of her divine change, and because of her faith, Paul counted her amongst all the holy people such as Abel, Abraham, Noah and Moses.

Origen (Selections on Joshua MPG 12.820) gives another reason why

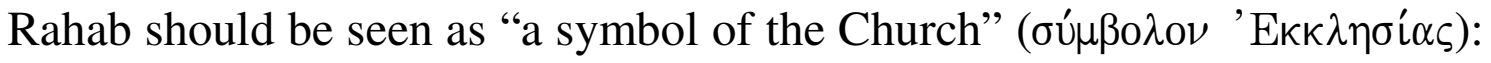
The stem of the name Rahab means "to be wide or broad". This shows that Rahab foreshadowed the Church which came forth from all nations.

\section{Rahab as a patroness of salvation}

Rahab is also called a "patroness of salvation" ( $\sigma \omega \tau \eta \rho i \alpha \varsigma ~ \pi \rho o ́ \xi \in \nu \circ \varsigma)$ since she displays what is necessary to obtain salvation (Chrysostom, On Repentance MPG 49.330). Rahab did not receive salvation merely because she received the spies in peace. Chrysostom makes it clear that any hostess ( $\pi \alpha \nu \delta \circ \chi \in \cup \tau \rho i \alpha)$ would do the same without being saved. But Rahab's hospitality proceeded from her faith and from her "attitude towards God"

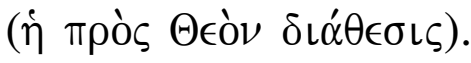




\section{Rahab as a representative of foreigners}

Several Church Fathers regarded Rahab as a representative of pagan nations. Theodoretus (Questions on the Octateuch, on Joshua 8; see also Questions on Ruth 1) says that since Rahab was a foreigner ( $\alpha \lambda \lambda$ ó $\phi 0 \lambda \circ \varsigma$

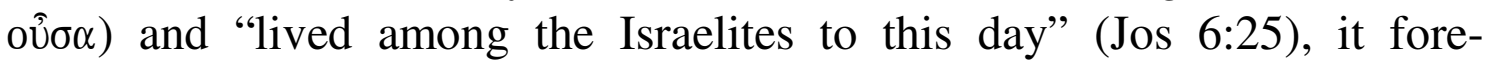
shadowed that the salvation of Christ was meant for all of us. He says that Christ himself confirmed this when He said: "I have other sheep that are not of this sheep pen. I must bring them also. They too will listen to my voice, and there shall be one flock and one shepherd" (Joh. 10:16). This same idea is also found in Epiphanius of Salamis (Against Heresies vol. 3, 62) who also says that Rahab, the harlot, who was "from a different tribe

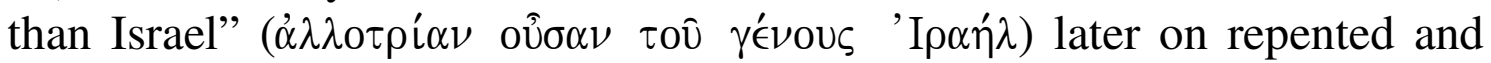
accepted the mercy of the God of Israel.

\section{Rahab lived in the world}

Gregory of Nazianzus uses the account of Rahab (Orat. 40) in a very interesting debate: On January 6, 381 he delivered a sermon on baptism. He encouraged people to be baptized, and then to withdraw from public life in order not to be exposed to sins. Yet, he argues, if one has already become entangled in secular affairs, one may still receive baptism without leaving the secular world. It is better to be baptised and to be somewhat stained by the sins of the world, than not to be baptised at all. Gregory argues that God is a just and merciful judge who will always look at our position in the society. A person who had only little success in his/her spiritual life while living among sinners, will receive a greater reward than the person who lived in a secluded area far from the sins of the world, but who has nevertheless not completely succeeded. And then Gregory uses two examples: Rahab, the harlot, led a sinful life, but was justified by one thing only, her hospitality, while the rest of her life was not praised. Gregory adds another example: the publican was saved just because of his humility, while the rest of his life was full of sins.

\section{Rahab and other sinners}

In the Apostolic Constitutions (2.3.14) it is argued that righteous people will not be punished with sinners, though they converse with them. The theological principle that everyone will have to give account of himself/herself is clearly emphasized. Rahab and Lot are then used as examples to proof this theological axiom: Lot was not destroyed by fire 
with the Sodomites, neither was Rahab slain with the inhabitants of Jericho.

\section{Rahab and Joshua/Jesus}

The Hebrew name for Joshua is Yeshua, which is a shortened form of Yehoshua. This is, of course, also the Hebrew equivalent of the Greek

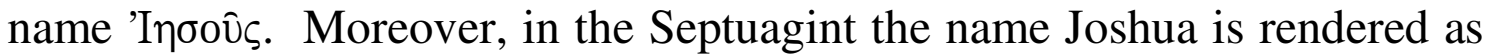
'Inбoûs (= Jesus). One can, therefore, see why it was so popular amongst the Church Fathers to see Joshua as an Old Testament type of Jesus.

Cyril of Jerusalem (Catechetical Lectures 10.11), for example, says that Joshua was in many respects a type of Jesus:

- Joshua began his rule over the people at the river Jordan (Jos. 3:1), and Jesus also began to preach the Gospel after $\mathrm{He}$ was baptized in the river Jordan.

- Joshua appointed twelve leaders to divide the inheritance (Jos. 14:1), and Jesus sent forth twelve apostles as heralds of the truth.

- Joshua saved Rahab the harlot when she believed, and Jesus said: "Behold, the publicans and the harlots go before you into the kingdom of God."

\section{Rahab and Zacchaeus}

Amphilochius (On Zacchaeus, orat. 8) connects the account of Zacchaeus with the account of Rahab. According to Amphilochius, the Gospel writer explicitly mentions that Jesus' encounter with Zacchaeus took place in Jericho, since he wants to remind his readers of the harlot Rahab who also lived in Jericho, and to highlight the salvation of both: Rahab, the harlot

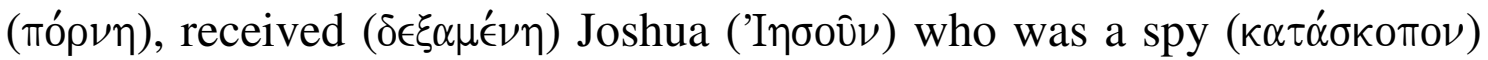

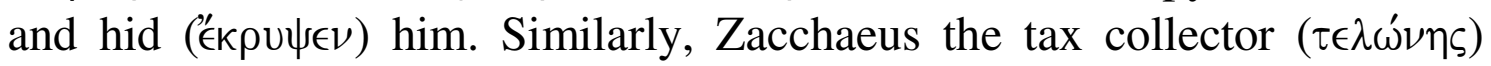

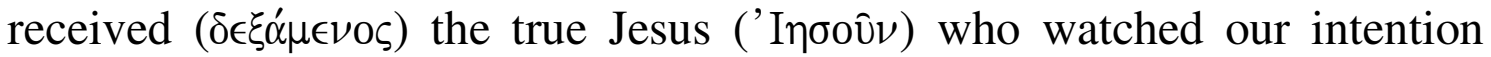

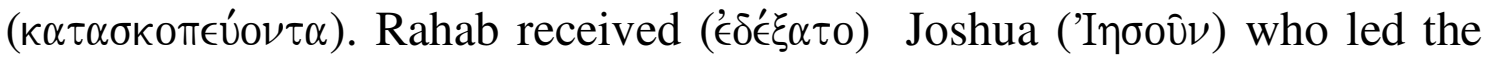
people into the promised land. Zacchaeus received ( $\left.\delta^{\prime} \in € \epsilon \tau \alpha \iota\right)$ the true Jesus

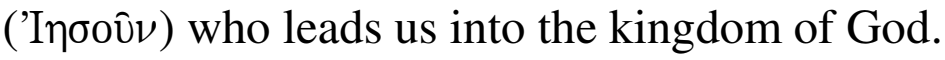

\section{Rahab and the sinful woman}

Several Church Fathers (see, for example, Romanos Melodos Hymn 21(SC114); Chrysostom, On the holy Passover, sermon 1) linked the 
account of Rahab with the story about the sinful woman who wept at Jesus' feet, and who wiped them with her hair, kissed them and poured perfume on them (Luk 7:36-50). In both narratives a prostitute received salvation after meeting' 'I

\section{Rahab and the role of women}

The Word of God teaches us that we should rescue one another from danger and from evil (Chrysostom, In Psalm 139, MPG 55.709). And this is not only the task of men. Chrysostom says that the Word of God teaches us that women too have the task to rescue us from evil and danger. He then names numerous examples, such as Sarah who saved Abraham from the hand of Abimelech (Gen. 20), Rebekah who saved her son Jacob from the hand of his brother Esau (Gen. 27), Michal who saved David from the hand of Saul (1 Samuel 19), and, of course, Rahab the harlot who saved the spies from the hands of their enemies in the city (Chrysostom, In Psalm 139, MPG 55.709).

\section{Rahab surpassed Israel}

Rahab proclaimed in a brothel what Israel denied in the desert (Chrysostom, On penitence MPG 49.330). God told Israel that there is no other god but the God who is in heaven above, and on the earth below. Israel had witnessed the acts of God, yet they asked Aaron to make a calf for them, and they then praised man-made gods for leading them out of Egypt. Rahab, the harlot, did not experience the miraculous events in the desert, yet she proclaimed in the brothel: "We know what your God has done to the Egyptians." Chrysostom then contrasts the Jews who said to idols "These are your gods who led you out of Egypt", while the harlot assigned their salvation to God.

\section{Rahab is proof of God's love for man}

Chrysostom (On repentance MPG 49.330) says that it is remarkable that He who said in the Law "You shall not murder. You shall not commit adultery" now changed his message and said through Joshua "Let Rahab the harlot live". This new message illustrates God's love for mankind $(\phi\llcorner\lambda \alpha \nu \theta \rho \omega \pi i \alpha)$. It also foreshadowed the words of Jesus that "tax collectors and the prostitutes are entering the kingdom of God ahead of you" (Mt 21:31). Her previous condition ( $\kappa \alpha \tau \alpha \dot{\sigma} \sigma \tau \alpha \sigma \iota \varsigma)$ causes us to admire the change in her life $(\mu \epsilon \tau \dot{\alpha} \sigma \tau \alpha \sigma \iota \varsigma)$. 


\section{Rahab and cunningness}

Basil (Homilies on the beginning of Proverbs MPG 31.412) discusses two different types of cunningness. He says that history is full of examples of both types. The Gibeonite deception (Jos. 9) is an example of the bad type, while Rahab's trick to save the spies, is an example of the good type.

\section{Rahab and the lie}

When the king of Jericho had heard that some of the Israelites had come to spy out the land, he asked Rahab to bring out the men who had entered her house. She lied and said: "Yes, the men came to me, but I did not know where they had come from. At dusk, when it was time to close the city gate, the men left. I don't know which way they went. Go after them quickly. You may catch up with them" (Joshua 2:4-5). Not one of the Greek Church Fathers had a problem with Rahab's lie. As a matter of fact, Chrysostom (On repentance MPG 49.331) even calls out "O good lie! O

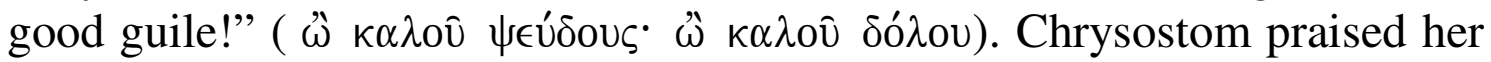
for her lie because her lie helped not to betray divine matters ( $\tau \dot{\alpha} \theta \in \hat{\imath} \alpha$ ), and

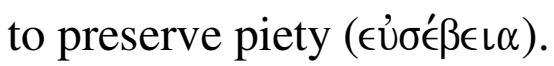

Moreover, Chrysostom praised Rahab for the wisdom which she displayed by mixing the truth with the lie. He said that if Rahab told them only a lie, they would not believe her. Therefore she started with the truth, and acknowledged the spies did visit her, but then she continued with a lie. And this helped to confuse the messengers of the King.

\section{Rahab and the spies under the stalks of flax}

Irenaeus (Against Heresies 4.20) says that the prophets in the Old Testaments not only saw visions about future events, and prophesied about what would happen, but there were also events which prefigured events in the New Testament. He uses Rahab the harlot as an example: she was a gentile, and guilty of many sins, but she nevertheless received three spies and hid them under the stalks of flax on the roof of her house (Jos. 2:6). Irenaeus then continues by saying that these three spies (it seems that Irenaeus forgot that there were only two spies) were types of the father and the Son and the Holy Spirit.

Origen (Selections on Joshua MPG 12.820) says that these stalks of flax were used to make linen which was also used to make the garment of the 
high priest. Rahab had the stalks of flax on her roof because she prepared them to make linen. One can almost say that Rahab regarded them worthy of the garment of a high priest (Origen, Selections on Joshua MPG 12.820).

\section{Resist Satan}

Chrysostom (On the circus MPG 59.570) says that we should resist Satan, as many other biblical figures have done. Jesus, for example, said: "Get behind me, Satan! You do not have in mind the things of God, but the things of men" (Mk 8:33). Others fled from evil, such as Elijah who fled from Jezebel (1 Kings 18). Neither should we allow Satan to lay hold of us, just as the king of Jericho could not lay hold of the spies. We should rather deceive Satan, just as Rahab, the harlot, deceived those who have come to capture the spies (On the circus MPG 59.570).

\section{Conclusions}

The narrative of Rahab was very popular amongst the Fathers of the Church. Though they continued to refer to her as Rahab, the harlot (móp $\nu \eta)$, they always used her story in a positive sense. Her previous questionable profession never counted against her. They used Rahab, inter alia, as an example of faith, and of hospitality, and of repentance, and as a model of the Church, as a patroness of salvation and as proof of God's love for man.

In her study of Rahab, McKinlay (1999:57) says that "different communities read textual dynamics in different ways, and that texts allow this". This is indeed what the Fathers also did when they interpreted the Rahabnarrative in the light of their own needs. They used the story of Rahab to guide the believers of their time. It reveals to us the Church Fathers' desire to make an Old Testament story relevant for the people of their times. Even in our post-modern times we can still learn from these ancient exegetes.

\section{BIBLIOGRAPHY}

Assis, E. 2004

"The choice to serve God and assist his people: Rahab and Yael" in Biblica, 85.1, 82-90.

Beek, M.A. 1982

"Rahab in the light of Jewish exegesis" in Von Kanaan bis Kerala (eds. Delsman, W.C., Nelis, J.T. et al.) [Alter Orient und Altes Testament]. Kevelear, Germany: Butzon und Bercker, 37-44. 
Boling, R.G. 1982

Joshua. A new translation with notes and commentary. (The Anchor Bible). New York: Doubleday \& Company, Inc.

Bratcher, R.G. \& Reyburn, W.D. 1991.

A Translator's Handbook on the Book of Psalms. New York: United Bible Societies.

Brown, R.E. 1982

"Rachab in Matt 1:5 probably is Rahab of Jericho" in Biblica, 63.1, 79-80.

Creach, J.F.D. 2003

Joshua. Series: Interpretation. Louisville: John Knox Press.

Gaster, T.H. 1962

"Rahab" in The Interpreter's Dictionary of the Bible. New York: Abingdon Press.

Greenspoon, L.J. 1992

"Rahab" in The Anchor Bible Dictionary (eds. Freedman, D.N. et al.). New York: Doubleday, pp. 611-612.

Hanson, A.T. 1978

"Rahab the harlot in early Christian tradition" in Journal for the Study of the New Testament, vol. 1, pp. 53-60.

Kroeze, J.H. 1968

Het Boek Jozua. Series: Commentaar op het Oude Testament. Kampen: N.V. Uitgeversmaatschappij.

McKinlay, J.E. 1999

"Rahab: A hero/ine"" in Biblical Interpretation, 7.1, 44-57.

Nelson, R.D. 1997

Joshua. A Commentary. Louisville: John Knox Press.

Newman, M.L. 1985

"Rahab and the conquest" in Understanding the Word (eds. Butler, J.T., Conrad, E.W. \& Ollenburger, B.C.) [Journal for the study of the Old Testament Supplement Series 37], Sheffield: JSOT Press, 167181.

Quinn, J.D. 1981

“Is PAXAB in Mt 1.5 Rahab of Jericho?" In Biblica, 62.2, 225-228.

Ross, J.F. 1962

"Rahab" in The Interpreter's Dictionary of the Bible. New York: Abingdon Press.

Stek, J.H. 2002

"Rahab of Canaan and Israel: The meaning of Joshua 2" in Calvin Theological Journal, 37, 28-48.

Wall,. R.W. 2001 
"The intertextuality of Scripture: The example of Rahab (James 2:25)" in The Bible at Qumran. Text, shape and interpretation (ed. Flint, P.W.). Grand Rapids: Eerdmans, 217-240.

\section{NOTES}

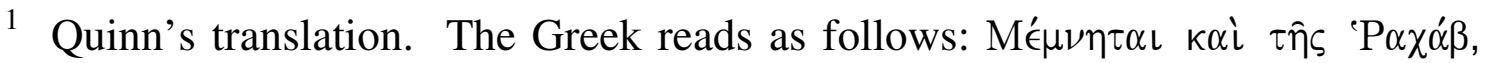

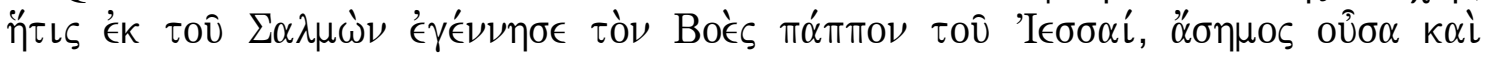

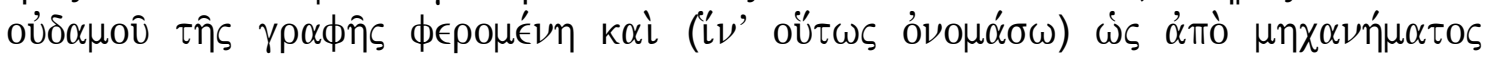

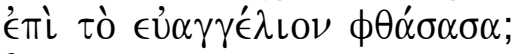

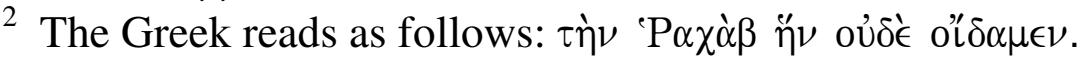

${ }^{3}$ See also Athanasius, Homilies on sacred Fathers and prophets, MPG 28.1064.

${ }^{4}$ See, for example, also Isa. 30:7.

${ }^{5}$ It is clear that Chrysostom regards Paul as the author of the Book Hebrews. 